\title{
REPORT OF THE XVIIth GENERAL ASSEMBLY OF \\ THE INTERNATIONAL ASTRONOMICAL UNION
}

\section{(RESOLUTIONS INCLUDED)}

\author{
AGENDA
}

First Session

1. Formal opening of the General Assembly, by the President

2. Appointment of official interpreters

3. Report of the Executive Committee:

(a) Discussion of the printed report, as published in the IAU Information Bulletin No. 42 of June 1979.

(b) Report of decisions taken at the meeting of the Executive Committee at Montreal, in particular as regards the admission of new Members

4. Oral report of the General Secretary

5. Report by the President on the proposals for membership in the Executive Committee for the period 1979 - 1982

The Special Nominating Committee has proposed the appointment of the following Officers for the term 1979 - 1982:

President: Prof. Dr. M.K.V. Bappu Indian Institute of Astrophysics Bangalore- 560034 India

Vice-Presidents :

Dr. M.W. Feast, South Africa (to continue until 1985)

Dr. L. Kresak, Czechoslovakia (to continue until 1985)

Prof. R. Wilson, United Kingdom (to continue until 1985)

The Vice-Presidents continuing from the previous term are: Dr. D.S. Heeschen, U.S.A. (until 1982)

Academician E.K. Kharadze, U.S.S.R. (until 1982)

General Secretary: Prof. S. van den Bergh, Canada (until 1982)

Castleknock, Co.
Assistant General Secretary: Prof. P.A. Wayman, Director, Dunsink Observatory, Castleknock, Co. Dublin, Ireland

Dr. R.M. West, Eso Sky Atlas Laboratory ESO TP Division, CERN, $\mathrm{CH}-1211$ Geneva, Switzerland Advisers: Prof. Dr. A. Blaauw - former President Prof. Dr. Edith A. Muller, - former General secretary

6. Announcement of:

(a) the names of representatives of Adhering Organizations empowered to vote on their behalf

(b) the names of representatives to serve on the Nominating Committee 
(c) the names of Acting Presidents of Commissions

7. Appointment of the Finance Committee

8. Appointment of the Resolutions Committee

9. Consideration of motion presented by the Executive Committee:

The Executive Committee proposes that statute 18 (a), as in IAU Transactions, vol. XIVB, be reworded as follows:

"18 (a) For each ordinary General Assembly the Executive Committee prepares a budget proposal covering the period to the next ordinary General Assembly, together with the accounts of the Union for the preceding period. It submits these to the Finance Committee for consideration: this Finance Committee consists of one member nominated by each adhering body and approved by the General Assembly. At the first meeting during the General Assembly, the Finance Committee elects a Chairman from among its members.

"18 (b) The Finance Committee examines the accounts of the Union from the point of view of responsible expenditure within the intent of the previous General Assembly, and it considers whether the proposed budget is adequate to implement the policy of the General Assembly as interpreted by the Executive Committee. It submits reports on these matters to the General Assembly which approves the accounts and decides on the budget."

Paragraphs (b), (c), (d), and (e) of statute 18 in force to become paragraphs (c), (d), (e) and (f) respectively.

To become valid, this change of statutes requires the approval of at least two thirds of the votes of Adhering Countries having the right to vote by virtue of statute $11(a)$.

10. Consideration of motions presented by Adhering Countries:

(a) The French National Committee of Astronomy has brought forward the following motions for adoption by the General Assembly:

(i) lst Motion

Le Comité National Francais d'Astronomie souhaite que le Comité Exécutif de l'Union Astronomique Internationale essaie, dans toute la mesure du possible, d'augmenter la proportion des dépenses scientifiques par rapport aux dépenses administratives. Il félicite Madame le secrétaire Général pour les efforts déjà accomplis dans ce sens.

(ii) 2nd Motion

Compte tenu du développement important de l'Astronomie en République Populaire de Chine, le Comité National Francais d'Astronomie demande au Comité Exécutif de l'Union Astronomique Internationale de poursuivre, au sein des statuts actuels de l'U.A.I., tous les efforts nécessaires à l'entrée de ce pays à l'U.A.I.

(iii) 3rd Motion

Le Comité National Francais d'Astronomie demande que soit soumise à l'approbation de l'Assemblée Générale de l'Union Astronomique Internationale de Montréal la proposition suivante: 
"Les Assemblées Générales de 1'U.A.I. ont lieu tous les 4 ans; la décision pourrait prendre effet en 1985 afin d'éviter la simultaneité avec les Assemblées Générales des disciplines voisines (COSPAR, UGGI)."

(b) The Swedish National Committee of Astronomy proposed that:

"The IAU should, possibly in collaboration with other organizations, establish a number of fellowships and/or grants, reserved for students in astronomy from developing countries. The financial aspects and the formulation of rules for such fellowships or grants should be considered by the relevant IAU committees and commissions. The individual IAU members and member organizations are urged to investigate their possibilities to find financial support for this project."

11. Consideration of motions presented by IAU Commissions:

(a) IAU Commission No. 6 "Astronomical Telegrams" proposes that the General Assembly increase the triennial IAU contribution to the IAU Telegram Bureau to SFrs 5,700.--.

(b) IAU Commission No. 10 "Solar Activity" proposes that the General Assembly adopt the following resolution:

"The General Assembly of the International Astronomical Union -noting that there are plans to discontinue the continuous observations from which the zurich sunspot numbers are derived,

-strongly recommends to the appropriate national organization the continuation of these long term observations which are vital and irreplaceable for improvement of our understanding of solar-terrestrial relationship."

(c) IAU Commission No. 20 "Positions and Motions of Minor Planets, Comets and Satellites" proposes that the General Assembly increase the triennial contribution to the Minor planet center over and above SFrs 6,220.--.

(d) IAU Commission No. 22 "Meteors and Interplanetary Dust" moves that the Commission consider the following resolution for adoption:

"Recognizing the major significance of comets for the study of the origin and evolution of the solar system in general and the interplanetary solid material in particular,

-noting the extreme diversity among individual comets in terms of composition, structure and physical behaviour, and

-conceding that ground-based observations are largely inadequate for establishing unequivocally the nature of the relationship between comets and other objects in the solar system

Commission 22 recommends that a vigorous program of space exploration of comets be initiated. To insure the maximum science return the program should include more than one comet and should proceed from rendez-vous missions to sample-return missions. A rendez-vous mission to $\mathrm{P} / \mathrm{Temple} 2$ in 1988 with 
an en route flyby of $\mathrm{P} / \mathrm{Halley}$ in 1985 , currently considered by NASA, is regarded as an ideal first step in the programme." the programme."

(e) IAU Commission No. 24 "Photographic Astrometry" proposes tentatively that the General Assembly adopt the following resolution:

"The IAU General Assembly strongly supports the independent and complementary astrometric programmes proposed for the ESA Astrometry Satellite and the NASA Space Telescope."

(f) IAU Commission No. 30 "Radial Velocities" provisionally proposes that the General Assembly approve to change the name of the Commission to "Stellar Radial Velocities."

(g) IAU Commission No. 44 "Astronomical Observations from Outside the Terrestrial Atmosphere", IAU Commission No. 10 "Solar Activity" and IAU Commission No. 12 "Radiation and Structure of the Solar Atmosphere" propose the following resolution:

"Noting the coming of Solar Maximum, Commission 44 wishes to encourage a sustained and coordinated effort in its study during the next 3 years."

12. Proposal and presentation by the Executive Committee of the budget of the IAU for the term 1980 - 1982 .

Second Session

13. Report of the Finance Committee

(a) Accounts of the IAU for 1976 - 1978

(b) The residual budget for 1979

(c) The budget for the ensuing term of office $1980-1982$

(d) The unit of contribution for the triennium $1980-1982$ The Executive Committee will propose to the Finance Committee that the unit of contribution be maintained at 1,465.- Swiss francs.

14. Appointment of the Special Nominating Committee

15. Proposals for resolutions presented by the Executive Committee

16. Proposals for resolutions presented by Adhering Organizations, subject to the recommendation by the Resolutions Committee

17. Proposals for resolutions proposed by IAU Commissions, subject to the recommendation by the Resolutions Committee

18. Announcement of new individual Members of the IAU

19. IAU Commissions:

(a) Structural changes in Commissions, if any

(b) The election of Presidents and Vice-Presidents

(c) The membership of Organizing Committees 
20. Place and date of the XVIIIth General Assembly

21. Election of President, three Vice-Presidents, General secretary, and Assistant General secretary

22. Addresses by retiring and newly elected officers

23. Closing Ceremonies

At the first session of the General Assembly, held on Tuesday 14 August, items 1 through 12 were considered. The remaining items were considered at the second session, held on Thursday, 23 August.

\section{FIRST SESSION}

\section{Formal Opening}

The President welcomed the Members of the Union, Invited Participants, Registered Guests, the representatives of adhering countries and National Committees of Astronomy, and the representatives of sister Unions and other organizations, and formally opened the first session of the seventeenth General Assembly of the International Astronomical Union in the Wilfrid-Pelletier Hall, place des Arts, Montreal, Quebec, Canada, on Tuesday, 14 August 1979 at 13.00 hours.

He wished a particularly hearty welcome to the official representatives of ICSU and sister Unions as follows:

ICSU (International Council of Scientific Unions):

IUGG (International Union of Geodesy and Geophysics):

IUGS (International Union of Geological Sciences):

IUPAC (International Union of Pure and Applied Chemistry):

IUWDS (International Ursigram and World Days Service) :

SCOSTEP (Scientific Committee on Solar Terrestrial Physics) : Prof. M.R. Kundu

COSPAR (Camittee on Space Research):

CCIR (International Radio Consultative Committee)

FAGS (Federation of Astronomical and Geophysical Services):

IPMS (International Polar Motion Service)

IUCAF (Inter-Union Commission on Frequency Allocation for Radio Astronomy and Space Science):

IUCS (Inter-Union Commission for Spectroscopy):

BIH (Bureau International de l'Heure):
Prof. J. -C. Pecker

Prof. P. Pâquet

Dr. W.W. Hutchinson

Prof. C. Sandorfy

Prof. D.B. Tonks

Dr. P. Simon

Prof. L.E. Peterson

Prof. J.P. Hagen

Dr. H. Enslin

Dr. S. Yumi

Dr. K. Yokoyama

Dr. G. Westerhout

Prof. J.G. Philips

Dr. B. Guinot 
ESA (European Space Agency):

Dr E. Peytremann

UNESCO (United Nations Educational, Scientific and Cultural organization) regretted not being able to be represented and sent best wishes.

The President suggested that messages of good wishes be sent to former Presidents and General Secretaries of the Union prevented from attending the present meeting. This suggestion was approved by acclamation. The meeting also approved by acclamation the proposal of the President that a special word of good wishes should be sent to J.G. Bolton, a Vice-President, absent due to illness.

The President then asked those present to stand while the General Secretary would read the names of Members who had died since the XVIth General Assembly, or whose death had not been known at the time of that meeting. The General secretary read the following list:

\author{
G. Adamopoulos \\ C.S. Beals \\ P.L. Bhatnagar \\ P.M.S. Blackett \\ M. Bloch \\ N. Boneff \\ M. Bonneau \\ z. Brkic \\ H.E. Butler \\ G.J. Carpenter \\ G. Cecchini \\ D. Chalonge \\ V.I. Chenakal \\ A. Couder \\ C. Cruz-Gonzales \\ I. Curea \\ G.Z. Dimitroff \\ H. Dingle \\ C.T. Elvey \\ V.I. Ezerskij \\ V.V. Fedynskij \\ E. Fichera \\ W.S. Finsen
}

\author{
M. Gentili de Giuseppe \\ J.E. Gordon \\ H. Haffner \\ Y Hagihara \\ M. Harwood \\ J.P. Heard \\ S.S. Huang \\ J. Hunaerts \\ M. Itzigsohn \\ S.A. Kaplan \\ D. Koelbloed \\ A. K. Korol \\ B.V. Kukarkin \\ I. Kupo \\ G.V. Lacchini \\ C. G. Lacombe \\ A. Lallemand \\ D.N. Limber \\ Y.H. Lipakij \\ J.A. Madeira \\ S.W. McCuskey \\ D. H. Menzel \\ V-V. Michkovitch
}
A.A. Nefd'ev
J.J. Nissen
P. Th. Oosterhoff
D.R. Palmer
R. Plátzeck
C. Popovici
A. Postoiev
H. H. Rabben
K. Reinmuth
G. Rịghini
V. Rijves
H. U. Sandig
H.K. Sen
S.F. Smerd
B. Sticker
E. Stiefel
N. Stóyko
A.D. Thackeray
P.J. Treanor
J. Ueta
E. Vandekerkhove
H. vón Klüber

\section{PRESIDENTIAL ADDRESS}

The President:

Before proceeding to the business of this Assembly, I should like to make a few general remarks. I know that most of you have come here in anticipation, first of all, of the many scientific meetings scheduled for the coming ten days. Naturally, this is the principal substance of the Assembly, and we are extremely pleased to see the scientific menu that lies before us. Just to mention a few of the attractive dishes: there are, outside the regular commission meetings, the eight 
joint discussions, most of them covering a full day, and all of them dealing with topics of great current interest, ranging from the most recent discoveries in the solar system to the rapidly developing field of extragalactic high-energy astrophysics. Adding to these the invited evening discourses to be presented to us by three very distinguished speakers, we see a programme that in itself would provide ample justification for our being here these ten days. But then, this is only part of it; meetings, sometimes joint meetings, of commissions will keep us equally busy, and let us not forget that it is one of the principal functions of the Union, to bring astronomers together from all over the world, to renew acquaintances or make new ones, and to promote the many private talks that are so essential to our research work.

With a programme so rich, and of such variety, we cannot but regret that financial and other circumstances prevent many more members of the Union being with us. The limited availability of travel grants, be it on the part of our sponsoring organizations or from the IAU itself, is one of the worries of the Executive Committee, and this is felt even more strongly now that almost everywhere in the world support for pure science, including astronomy, tends to be reduced. Naturally, this affects particularly the attendance from countries remote from the location of the General Assembly. It is, therefore, a very good tradition that successive assemblies are held in different parts of the world and we encourage by all means invitations for future assemblies to continue this tradition wherever possible.

The world wide character of the IAU's activities is not, however, restricted to just the triennial assemblies, and the symposia and colloquia; there is much more to it. As this may not be so apparent, especially not to the many younger ones among you, let me remind you of some of these other activities. Since some ten years ago, the IAU, in the spirit of what I have just said, has encouraged regional astronomy meetings to be held in different parts of the world, in order to promote international contact for IAU members and students, especially in those countries where the financial difficulties are great or even prohibitive for attending assemblies or the regular IAU symposia and colloquia. The past three years have seen three such regional events - all of them very successful. In all these cases the initiative came from within the geographical regions, but it was the IAU's relatively small subsidy and its support as an international organization, that helped turn these local initiatives into successful international gatherings. The IAU also sees it as its task, to help develop teaching in astronomy in those parts of the world where, in the struggle for economic and cultural development, virtually no expertise and money can be set aside for the promotion of a science like ours, from which the returns cannot be more than a promise for a distant future. I am referring to the young astronomers' schools for which, again, successful initiatives were honoured in recent years. As a third activity, beneficial from the points of view of both education and research, let me mention the funding of the exchange of astronomers, in this case through one of our commissions specially created for this task. I would like you to be well aware of this possibility offered by our Union, and make good use of it. of all these examples of IAU activities, and of many more, the report of the General Secretary, whose office is an action centre 
for many of these activities - will give more particulars. Let me mention that, for the realization of some of these special projects, the IAU benefits much from grants received from the International Council of Scientific Unions.

The International Astronomical Union, as has been said before at our Assemblies, symbolizes the unity and common goals of astronomers and astronomy from its 48 adhering countries, virtually covering the whole world.

In this context, I wish to say a few words on an item of special importance; that item is the restoration of full participation of Chinese astronomers in the Union. The absence of astronomers from the mainland of China at our General Assemblies since 1961 has been a matter of great concern for members of the Union, and therefore also of the Executive Committee; and that is particularly true for the present Executive Committee and that of the preceding period. Many of you will remember the words spoken with regard to this problem by the previous president of the IAU, Professor Leo Goldberg, at the Grenoble Assembly. To me, and to my fellow officers, it seemed one of the most urgent problems to take up when we assumed our duties three years ago.

I am therefore extremely pleased that I am in a position to tell you that good progress has been made lately, and that perhaps it is not too optimistic to say that the restoration of the full adherence of astronomers of all parts of China is in sight. That we have been able to make this step forward, we owe above all to the contructive spirit in which this problem has been approached by all parties involved. We have been very fortunate in having had with us here in Montreal, for almost a week now, delegations of the astronomical communities of both the mainland of China and Taiwan, so as to approach the solution further, following the preparatory discussions and correspondence; in these preceding activities also, many astronomers outside the officers of the Union have participated for which we are most grateful.

The presence of the delegation of our colleagues from the mainland of China, under the chairmanship of Prof. Y.C. Chang of Purple Mountain observatory, during the scientific meetings which we are now about to start, will, I am sure, render extra flavour to these meetings. Not only will we become much better aware of the progress of astronomy on the mainland of China and, at last, be in a better position to share with them the progress in astronomy in other parts of the world, but I believe this experience should also strengthen our awareness of the rewarding, albeit modest, role we scientists, and particularly we astronomers, can play in bridging the gaps that unfortunately tend to keep this world divided. I sincerely hope that by the time of the conclusion of this General Assembly, I may be in a position to inform you in more detail on the arrangements that we have been been able to make in this matter. 


\section{Appointment of Official Interpreters}

The General Assembly appointed by acclamation S. Demers as official interpreter from English to French, and R. Racine as official interpreter from French to English.

\section{Report of the Executive Committee}

The General secretary invited the national representatives to discuss the Report of the Executive Committee to the General Assembly, as published in IAU Information Bulletin No. 42 (see also pp. 497-523 below). There was no discussion and the Report was approved unanimously.

\section{Report of the General Secretary}

The President gave the word to the General Secretary who presented to the General Assembly her supplementary report for the period from 1 January to 13 August 1979 as follows:

This brief report summarizes the activities of the Union from ist January 1979 until now.

The President, General Secretary and Assistant General Secretary held their last officers' meeting in Geneva, Switzerland, on 19 May 1979, during which they discussed the most important problems of the IAU such as its finances, the forthcoming General Assembly and its scientific content, applications for membership to the Union, etc.

The Executive Committee continued its work by correspondence. It was twice informed of the amendments to the comprehensive budget of the IAU and it approved these amendments. It also approved the triennial report prepared by the General secretary which has been published in Information Bulletin No. 42 as Report of the Executive Committee to the XVIIth General Assembly, and appears in Appendix I of this volume.

The agenda of the XVIIth General Assembly, as formulated by the Executive Committee, was distributed to Adhering Organizations and/ or National Committees of Astronomy before the statutory deadline. To assist attendance about 170 Young Astronomers' Grants have been allocated, as previously approved by the Executive Committee. Their amount varied with geographical location of the beneficients. The greater part of these grants are to be paid in cash here in Montreal. The Canadian National Committee offered to exempt the recipients of IAU Young Astronomers' Grants from paying the registration fee. In the name of the IAU and the recipients of the grants, I thank the Canadian National Committee most sincerely for their generosity.

Cooperation with the Canadian organizers of this Assembly was most pleasant and fruitful, and for this I wish to thank in particular Dr. Alan H. Batten, Chairman of the Canadian Committee for the XVIIth General Assembly, Dr. Gilles Beaudet, Chairman of the Local Organizing Committee, and Mlle. Madelaine Bergevin, Secretary of the Committee.

The reports of Presidents of Commissions, prepared in cameraready typescript, were edited and sent to the printer. They have 
appeared, in 3 parts, as IAU Transactions volume XVIIA, subtitled Reports on Astronomy 1979. On behalf of the Union I wish to thank our Presidents of Commissions, and all those who cooperated with them, for their fine reports. My thanks are also due to our publisher, the D. Reidel Publishing Company, for having brought out the Reports well before the General Assembly.

Apart from the many scientific meetings and sessions planned for the forthcoming 10 days of the present General Assembly - which as you can see from the programme promises to be a very interesting one - a number of Symposia and Colloquia have been planned around the General Assembly. Three Symposia and two Colloquia were held immediately before the General Assembly, and four Symposia and one Colloquium will be held shortly after its termination.

Commission No. 46 (Teaching of Astronomy) is organizing a Young Astronomers'School which is to be held at the Instituto de Astrofisica de Canarias in La Laguna, Tenerife, Spain, from 10 to 22 september 1979. This school has the financial support of a UNESCO through ICSU contract in the amount of US $\$ 4000 .--$ which the IAU will match with the same amount. The director of the School is Prof. Francisco Sanchez, and its Secretary is Dr. Josip Kleczek who has a long experience in the organization of these schools. The lectures will be given in Spanish.

One of the tasks of the General secretary during her term was to plan for the permanent seat of the IAU Secretariat on the premises of the Observatoire de Paris, in Paris, France, and to select the new staff members. Mesdames, Messieurs: Vous vous rappelez peutêtre que lors de la dernière Assemblée Générale à Grenoble, Madame Alice Saunier-Séité, Ministre des Universités, invita l'Union Astronomique Internationale à installer son secrétariat permanent à $l^{\prime} \mathrm{Ob}-$ servatoire de Paris dans de locaux spécialement mis a notre disposition. J'ai le plaisir de vous annoncer que le pavillon ouest de l'Observatoire de Paris a été aménagé poúr accueillir en permanence notre secrétariat; les travaux de réfection du pavillon sont achevés et le nouveau mobilier installé, l'ensemble donnant un cadre de travail agréable et accueillant. Je tiens à remercier au nom de I'UAI les responsables du Ministère des Universités de France et de l'Observatoire de Paris pour l'aménagement de ces locaux. En particulier, je remercie vivement Monsieur J. Boulon, Président de l'observatoire de Paris, Monsieur J. Delhaye, Directeur de l'INAG, et Monsieur J.C. Pecker, Professeur au Collège de France et ancien Secrétaire General de I'UAI, pour toutes les interventions et l'appui gu'ils m'ont apportés dans le choix et l'aménagement des locaux pour l'emplacement permanent du secrétariat de l'UAI. De plus, je remercie très sincèrement le collège de France qui, par l'intermédiaire de J.-C. Pecker, a offert au secrétariat de I'UAI une machine à écrire IBM, - un somptueux cadeau. Un grand MERCI:

The permanent seat of the IAU secretariat has also space for the Union's archives which, therefore, will be moved from Belgium and from Czechoslovakia to Paris. In the name and on behalf of the IAU I thank Prof. A. Velghe, Director of the Observatoire Royal de Belgique, and Dr. V. Bumba, Director of the Astronomical Institute of Czechoslovakia, for having kindly hosted the IAU archives, for many years, at their observatories in Bruxelles and in ondrejov respectively. 
As regards the finances of the IAU I am happy to report that the meeting of the ICSU General Committee held in Brussels, Belgium, from 2 to 6 July, allocated to the IAU a UNESCO through ICSU subvention of US $\$ 8000 .--$ instead of the expected US $\$ 6000 .--$ for 1980, and that, in addition, it granted the Union for the same year some UNESCO/ICSU contracts in the amount of US $\$ 8000 .--$. The comprehensive draft budget for 1980-82 was, therefore, slightly revised accordingly. The revised version of the budget will be presented to the Finance Committee.

I am also happy to announce that at the same recent meeting the ICSU General Committee allocated to the IAU a further grant of US $\$ 3$ 000.-- to be used as travel subsidy for the participation of Dr. S.E. Okoye of Nigeria and Dr. E. Bajaja of Argentina at the world Administrative Radio Conference (WARC) to be held this fall of 1979, over about 10 weeks, in Geneva, Switzerland.

I am pleased to inform you that at present the finances of the union are in a very satisfactory state.

It is with great pleasure that I have received, shortly before the General Assembly the application of Indonesia to become a Member Country of the Union. The Executive Committee examined this application and arrived at the conclusion that the development of astronomy in Indonesia had reached a level that satisfies the conditions for admission to the Union.

In conclusion, I wish to express my sincere thanks to the Chairmen of National Committees of Astronomy, to the Presidents and VicePresidents of Commissions, and to all those who contributed to the successful work of the IAU during my term of office.

On the proposal of the General Secretary, the Assembly then approved unanimously to include in the agenda the application of Indonesia for admission to the Union as an adhering country.

5. Report of the Fresident on the proposals for membership in the Executive Committee for the term 1979 - 1982.

The President informed the Assembly that Article 12 (a) of the By-laws provides that proposals for election to the President of the Union, six Vice-Presidents, the General Secretary and the Assistant General Secretary are submitted to the General Assembly by the special Nominating Committee. The present special Nominating Committee, consisting of the President in office, the past President L. Goldberg, a member nominated by the former Executive Committee, J.P. Wild, and four members elected by the Nominating Committee: A. Dollfus, B.A. Lindblad, A.G. Massevich and A. Reiz, had made the following proposals as to the composition of the next Executive Committee:

As President for the period 1979-1982:

As Vice-Presidents for the period 1979-
Prof. M.K.V. Bappu, India

Dr. M.W. Feast, S. Africa

Dr. L. Kresak, Czecho-

slovakia

Prof. R. Wilson, U.K. 
As General Secretary:

Prof. P.A. Wayman, Ireland

As Assistant General Secretary:

Dr. R.M. West, Denmark

The full Executive Committee is thus to consist of the above six together with:

Continuing Vice-Presidents:

Dr. D.S. Heeschen, U.S.A.

Academician E.K. Kharadze, U.S.S.R.

Prof. S. van den Bergh, Canada

In an advisory capacity:

Prof. A. Blaauw, outgoing President, The Netherlands

Prof. Edith A. Müller, outgoing General Secretary, Switzerland

According to the By-laws the formal election will take place at the final session of the General Assembly.

\section{Announcements}

Called on by the President, the General Secretary announced (a) the names of the representatives of adhering organizations to vote at the General Assembly

(b) the names of representatives of adhering organizations on the Nominating Committee:

COUNTRY

A.R. of Egypt
Argentina
Australia
Austria
Belgium
Brazil
Bulgaria
Canada
Chile
Colombia
Cuba
Czechoslovakia
Denmark
Finland
France
GDR
Germany, D.R.
A.S. Asaad
J.L. Sérsic
S.C.B. Gascoigne/
A.R. Hyland
H. Haupt
P. Swings
S. Ferraz Mello
M. Popova
A. I. Halliday
C. Anguita

NOMINATING

COMMITTEE

R. Ghobros

R. Colomb

B.Y. Mills

H. Haupt

M.P. Ledoux

P. Kaufmann

N. Nikolov

F.D.A. Hartwick

A. Gutierrez-

Moreno
V. Vanysek
H. Jørgensen
I. Tuominen
N. Bel
G. Ruben
G. Traving

A. Reiz

K. Lumme/

I. Tuominen

E. Schatzman/

J.-C. Pecker

G. Ruben

K. Hunger 


\begin{tabular}{|c|c|c|}
\hline COUNTRY & TO VOTE & $\begin{array}{l}\text { NOMINATING } \\
\text { COMMITTEE }\end{array}$ \\
\hline $\begin{array}{l}\text { Hungary } \\
\text { India } \\
\text { Iran } \\
\text { Iraq } \\
\text { Ireland } \\
\text { Israel }\end{array}$ & $\begin{array}{l}\text { L. Dezsö } \\
\text { G. Swarup } \\
\text { Y. Sobouti } \\
\text { M.A. Kaftan } \\
\text { P.K. Carroll } \\
\text { Yu Ne'eman/ }\end{array}$ & $\begin{array}{l}\text { B. Szeidl } \\
\text { S.K. Trehan } \\
\text { Y. Sobouti } \\
\text { M. Kaftan } \\
\text { P.K. Carroll }\end{array}$ \\
\hline $\begin{array}{l}\text { Italy } \\
\text { Japan }\end{array}$ & $\begin{array}{l}\text { A. Kovetz } \\
\text { M.G. Fracastoro } \\
\text { Y. Kozai }\end{array}$ & $\begin{array}{l}\text { Yu. Ne'eman } \\
\text { M. Hack } \\
\text { D. Sugimoto }\end{array}$ \\
\hline Korea PDR & & \\
\hline $\begin{array}{l}\text { Korea (Republic) } \\
\text { Mexico }\end{array}$ & $\begin{array}{l}\text { Y. Key-Minn } \\
\text { P. Pismis }\end{array}$ & $\begin{array}{l}\text { K. Chol-Chou } \\
\text { S. Torres-Peim- } \\
\text { bert }\end{array}$ \\
\hline $\begin{array}{l}\text { Netherlands } \\
\text { New Zealand } \\
\text { Norway } \\
\text { Poland } \\
\text { Portugal }\end{array}$ & $\begin{array}{l}\text { H. van der Laan } \\
\text { P.J. Edwards } \\
\text { E. Jensen } \\
\text { W. Iwanowska } \\
\text { J. Pereira Osorio }\end{array}$ & $\begin{array}{l}\text { T. de Jong } \\
\text { P.J. Edwards } \\
\text { R. Stabel } \\
\text { A. Opolski } \\
\text { A.J.F. Pereira } \\
\text { Pascoal }\end{array}$ \\
\hline $\begin{array}{l}\text { Roumania } \\
\text { South Africa } \\
\text { Spain } \\
\text { Sweden } \\
\text { Switzerland } \\
\text { Taiwan } \\
\text { Turkey } \\
\text { Uruquay }\end{array}$ & $\begin{array}{l}\text { G.D. Nicolson } \\
\text { J. Pensado } \\
\text { A. Elvius } \\
\text { U.W. Steinlin } \\
\text { Chun-Shan Shen }\end{array}$ & $\begin{array}{l}\text { E.E. Baart } \\
\text { F. Sanchez } \\
\text { P.O. Lindblad } \\
\text { M. Mayor } \\
\text { Chan-Shiann Tsai }\end{array}$ \\
\hline $\begin{array}{l}\text { U.K. } \\
\text { U.S.A. } \\
\text { U.S.S.R. } \\
\text { Vatican City State } \\
\text { Venezuela } \\
\text { Yugoslavia }\end{array}$ & $\begin{array}{l}\text { M.J. Seaton } \\
\text { E. von P. Smith } \\
\text { E.R. Mustel } \\
\text { M. McCarthy } \\
\text { D.J. MacConnell } \\
\text { G. Teleki }\end{array}$ & $\begin{array}{l}\text { R.J. Tayler } \\
\text { J.E. Gaustad } \\
\text { E.V. Kononovich } \\
\text { G. Coyne } \\
\text { D.J. MacConnell } \\
\text { G. Teleki }\end{array}$ \\
\hline
\end{tabular}

N.B. Where two representatives are shown for one adhering organization, it is understood that the persons would divide their atten-

dance according to their being available as alternatives.

(c) The General secretary announced that the Executive Committee had appointed the following Vice-Presidents of IAU Commissions to act for Presidents of Commissions unable to attend the General Assembly:

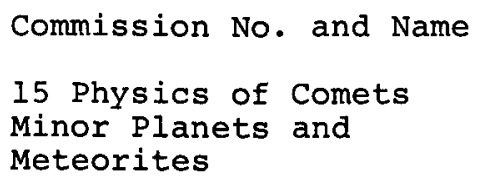

L. Dezsö

India

Iran

Ireland

Italy

Korea (Republic)

Netherlands

Norway

Poland 
7. Appointment of the Finance Committee

In accord with Statute 18 (a), the General Assembly appointed the following Finance Committee consisting of one representative of each adhering country:

Country

Arab Republic of Egypt

Argentina

Australia

Austria

Belgium

Brazil

Bulgaria

Canada

Chile

Colombia

Cuba

Czechos lovakia

Denmark

Finland

France

Germany, D.R.

Germany, F.R.

Greece

Hungary

India*

Iran

Irag

Ireland

Israel

Italy

Japan

Korea PDR

Korea (Republic)

Mexico

Netherlands

New Zealand

Norway

Poland

Portugal

Roumania

South Africa

Spain

Sweden

Switzerland

Taiwan

Turkey

Uruguay

U.K.

U.S.A.

U.S.S.R.

Vatican City state

Venezuela

Yugoslavia
Representative on Finance Committee

S. Moustafa

G. Carranza

W.H. Robertson

H. Haupt

A.G. Velghe

L. Muniz Barreto

M. Kalinkov

J. Tatum

$F$. Noel

not represented

not represented

J. Sykora

P.E. Nissen

P.E. Markkanen

F. Spite

G. Ruben

W. Fricke

S. Svolopoulos

L. Dezso

J.C. Bhattacharyya

Y. Sobouti

M. Kaftan

P.A. Wayman

G. Shaviv

G. Godoli

Y. Kozai

not represented

K. Chol-Chou

L. Carraso

H. van Voerden

P.J. Edwards

$\varnothing$. Elgaroy

S. Piotrowski

J. Pereira Osorio

not represented

B. Warner

L. Ouijana

T. Elvius

A. Zelenka

Chun-Shan shen

not represented

not represented

D. Walsh

P.B. Boyce

A.A. Boyarchuk

J. Sasanovas

J. Stock

I. Pakvor 


\section{Appointment of the Resolutions Committee}

At the request of the President, the General secretary informed the Assembly that the Resolutions Committee is to advise the Executive Committee and General Assembly as regards the proposals for resolutions submitted for consideration. The General Assembly appointed F.G. Smith, B. Hauck and A.A. Boyarchuk to serve on the Resolutions Committee, with the General Secretary and Assistant General secretary attending the meetings in an advisory capacity.

9 through 11 . Consideration of motion presented by the Executive Committee, of motions presented by adhering countries, and of proposals for resolutions submitted by Commissions.

The General secretary proceeded by reading the proposals for resolutions as under points 9,10 and 11 of the agenda. As regards the motion of the Executive Committee to change statute 18 (a) she said that, in correspondence, the British National Committee supported the change but had also suggested that the wording of the proposed statute 18 (b) might be clarified by changing its final sentence as follows: "It submits reports on these matters to the General Assembly for approval of the accounts and decision on the budget." The Executive Committee accepts this rewording, and the motion before the General Assembly would therefore read as follows:

That Statute 18 (a), as in the IAU Transactions, vol. XIV B, be reworded as follows:

"18 (a) For each ordinary General Assembly the Executive Committee prepares a budget proposal covering the period to the next ordinary General Assembly, together with the accounts of the Union for the preceding period. It submits these to the Finance Committee for consideration: this Finance Committee consists of one member nominated by each adhering body and approved by the General Assembly. At its first meeting during the General Assembly, the Finance Committee elects a Chairman from among its members.

"18 (b) The Finance Committee examines the accounts of the Union from the point of view of responsible expenditure within the intent of the previous General Assembly, and it considers whether the proposed budget is adequate to implement the policy of the General Assembly as interpreted by the Executive Committee. It submits reports on these matters to the General Assembly for approval of the accounts and decision on the budget."
Paragraphs (b)
(c),
(d), and
(e) of Statute 1
(f) respectively. paragraphs (c),
(d),
(e) and

The General Secretary announced that to become valid this change of Statutes would require the approval of at least two-thirds of the votes of adhering countries, having the right to vote by virtue of Statute 11 (a), at the Second Session of the General Assembly.

The representative of the French National Committee of Astro- 
nomy, J.-C. Pecker, said that the Executive Committee motion is of paramount importance for the life of the Union and the proposed resolution should therefore be carefully studied word by word.

For the same reason it would be necessary to provide a French translation of the motion.

The General Secretary promised that the Executive Committee would provide the French translation for the next session. Similarly, French and English translations, as the case may be, would be available for the motion of the Swedish National Committee, as under point 10 (b) of the agenda, and of the three motions of the French National Committee of Astronomy, as under point 10 (a) (i, ii, iii) of the agenda.

12. Proposal and presentation by the Executive Committee of the Budget of the IAU for the term 1980-1982.

Called on by the President, the General secretary said that the budget proposal for 1980-1982, as in the agenda, is a slightly changed version of the budget proposal circulated earlier to adhering organizations, and that attached to the agenda sent to National Committees of Astronomy. The change became necessary because ICSU had increased its contribution to the IAU for 1980. The budgetary items which benefited from this increase are (in Payments):

\author{
4.1 Exchange of Astronomers \\ 7. Publications for developing countries \\ 10. Symposia and Colloquia \\ 15. Young Astronomers' Schools
}

As an amendment to the budgetary proposal published in the agenda distributed earlier, this revised budget proposal will have to be brought on to the agenda of the General Assembly by a vote of not less than two-thirds of the adhering countries voting.

The President asked the Assembly to vote on this proposal by a show'of hands. The General Assembly was unanimous in its vote that the revised version of the budget for $1980-82$ be included in the agenda.

The General Secretary announced that all other items of the agenda would be deferred until the next session of the General Assembly. hours.

The President then formally adjourned the meeting at 15.00

\title{
SECOND SESSION
}

Held in the Pavillon Principal of the Universite de Montréal, Montréal, on Thursday, 23 August, from 10.15 to 13.30.

Professor A. Blaauw, President, in the chair

Before passing to the agenda, the General secretary, called upon by 
the President, established the quorum and found 5 adhering countries not represented. The General Assembly then appointed R. Gaizen and $M$. Ovenden as Tellers. The President read to the Assembly a message of good wishes received from Professor Cornelis de Jager, President of ICSU.

The General Secretary proposed that point 18 of the agenda be amended as follows:

18. Membership

(a) adherence of Indonesia

(b) membership of the Democratic Peoples' Republic of China

(c) individual membership

This proposal was carried unanimously.

13. The Finance Committee appointed at the first session was to examine the accounts of the Union for the years 1976-1978, the budget estimates of the Union for 1979 and for the period 1980-1982, and to consider the unit of contribution payable to the IAU by Adhering Countries for the next term of office. The President called upon Dr. H. van Woerden, member of the Finance Committee, to present to the General Assembly the report of that Committee as prepared by its Chairman, Prof. W. Fricke. Dr. van woerden read as follows:

\section{REPORT OF THE FINANCE COMMITTEE}

1. At the First Session of the XVIIth General Assembly on 14 th August 1979, the Finance Committee, consisting of the nominated representatives of Member Countries, was duly appointed to perform its duties in accordance with Article 18 (a) of the statutes. The Finance Committee met on that date when the IAU General secretary welcomed the members and outlined the function of the Committee. The IAU General Secretary explained that for each ordinary General Assembly the Executive Committee prepares an estimate of the budget for the period to the next ordinary General Assembly which it submits to the Finance committee, together with the accounts for the preceding period. The Finance Committee examines the accounts and the estimate of the budget on which it prepares reports and submits them to the General Assembly for approval.

2. The Finance Committee appointed W. Fricke as its chairman, and it appointed a sub-Committee to make a detailed examination of the accounts and of the estimate of the budget. The sub-Committee consisted of the Chairman ex officio, A.A. Boyarchuk (U.S.S.R.), P.B. Boyce (U.S.A.), A.G. Velghe (Belgium), with Ms. E.A. Müller, P.A. Wayman and $A$. Jappel members $e x$ officio as General Secretary, Assistant General Secretary and Executive Secretary of the Union respectively.

The budgetary estimates for 1979, summarized in the Report of the Executive Committee, were examined by the Finance Committee at its first session, and it was noted that the projected expenditure was within the financial provision of the Budget accepted by the 
General Assembly, and that it was consistent with the policy of the Union embodied in the Budget.

The Finance Committee recommends to the General Assembly that the budgetary estimates for 1979 be accepted.

3. The sub-Committee of the Finance Committee was convened by the Chairman on the 15th and 17th August, and it presented a report to the Finance Committee at its second meeting on 18th August. The Chairman reported to the Finance committee that the accounts for the period 1976-78, had been subjected to detailed examination by the sub-Committee with verifications supplied by the secretariat during the examination. It was noted that the accounts had been kept at a very high standard and that all the relevant documents were available. The sub-Committee had concluded that the accounts were in order, both on the basis of its own inspection and on the summary statement of the Auditor to the Union, M. Roger Bacle of Paris.

The Finance Committee, on the basis of the inspection of the accounts by the sub-Committee, recommends to the General Assembly that the accounts for $1976-78$ be approved.

4. The Sub-Committee reported to the Finance Committee that it had examined in detail the comprehensive budgetary proposals for the period 1980-82 submitted by the Executive Committee. It was noted that

(a) the Executive Committee had proposed to maintain the Unit of Contribution from adhering countries at the present level

(S. Frs. 1 465.00);

(b) the revenue from the IAU-publications and from interest on accounts was estimated with all possible care, and that

(c) UNESCO subventions through ICSU and UNESCO will certainly be not less than S. Frs. 47040.00 .

In considering the assessments of payments for the period 1980-82 it was noted that

(a) an amendment of the following items may be expected from UNESCO funds: (4.1) Exchange of Astronomers, (7) Publications for Executive Committee and eveloping countries, and (15) Young Astronomers' Schools;

(b) the amount for Symposia and Colloquia was increased by about 208 compared to that of the previous budget period, and that

(c) all the individual budget items and the adjustment of these items appeared to be proper and adequate to implement the policy of the Union.

5. The Finance Committee, on the basis of the report of the subCommittee, recommends for adoption by the General Assembly the following budget presented by the Executive Committee: 
BUDGET FOR 1980-1982

Unit of contribution 1456.00 Swiss Francs
(One Swiss Franc equal to $0.2175926 \mathrm{~g}$ of fine gold)

RECEIPTS in Swiss Francs

1. Contributions from Adhering Countries 966900

2. Revenue from the IAU publications

51000

3. Interest on accounts 82000

4. UNESCO contribution through ICSU \& UNESCO contracts 1980 47040

Total receipts

I 146940

Total payments

1146050

$======$

Excess of receipts over payments $89 \underline{9}$

Payments under item 4.3

(Other projects of Commissions)

Camissions and Projects SFrs

6. IAU Telegram Bureau 5700

16. Planetary Documenta- 5310 tion

17. Lunar Documentation 5310

20. Minor Planet Center 7200

27. Variable stars

Catalog

9330

Total
PAYMENTS in Swiss Francs

1. Administrative Office

1.1 Secretariat in Paris

380000

1.2 Secretarial help for the General Secretary and Assistant General Secretary

30000

1.3 Furniture, Typewriters 20000

2. Subscription to ICSU

24200

3. Cormission expenses

15000

4. Projects of Commissions 58000 4.1 Exchange of Astronomers

4.2 Teaching of Astronamy 3000

4.3 Other projects $\quad 32850$

5. General Assembly $\quad 140000$

6. IAU publications

55000

7. Publications for Executive Comittee \& developing countries

49000

8. Executive Committee meeting

60000

9. Officers' meeting

21000

10. Symposia \& colloguia

138000

11. Inter-Union Commissions

20000

12. Projects of the Executive Committee

13000

13. Representation

20000

14. Bank Charges

1000

15. Young Astroncmers' schools

37000

16. Regional meetings

24000

17. Expenses of Special

Nominating Committee

5000

Total Payments

1146050 
6. The Sub-Committee noted that the recommendation of the Finance Committee made to the XVIth General Assembly regarding the transfer of 60000 dollars from the current Accounts into savings Accounts was met by a transfer of 40000 dollars to American Savings Accounts and of 100000 S.Frs. to two Savings Accounts at the Union de Banques Suisses. The Finance Committee expresses its satisfaction with that action.

7. The Sub-Committee noted with satisfaction an increase of the earnings from interest. The Finance committee concurred with the view that the continuation of efforts in this direction should be encouraged.

8. The Sub-Committee stressed that the efforts for the exchange of astronomers must continue to be pursued. The funds might be augmented by UNESCO through ICSU grants. The Finance Committee considered such efforts as very important and recommends their continuation.

9. The Finance Committee supports the rewording and amendment of article 18 (a) of the Statutes as proposed by the Executive Committee in new articles 18 (a) and 18 (b) and recommends adoption by the General Assembly.

W. Fricke

Chairman, Finance Committee

The President thanked Dr. van woerden and put the report of the Finance Committee to the vote, first as regards the unit of contribution, then as regards the accounts of the IAU 1976-1978, and eventually as regards the budget estimates for the years 1979 and the next term of office 1980-1982. Voting on all these points was unanimously affirmative.

The President expressed the Union's appreciation of the work of the members of the Finance Committee and the Finance Sub-Committee, and especially of the work of the Chairman, Prof. W. Fricke.

\section{Appointment of the Special Nominating Committee}

The President referred to article 12 of the By-laws providing that proposals for election to the President of the Union, six-VicePresidents, the General Secretary and the Assistant General Secretary, are submitted to the General Assembly by the Special Nominating Committee. Proposals by Presidents of Commissions for membership of the SNC are reviewed by the representatives of adhering organizations on the Nominating Committee. Together with one proposal by the Executive Committee, this has resulted in a proposal that the General Assembly appoint the following members to serve on the special Nominating Committee for the period 1979-1982:

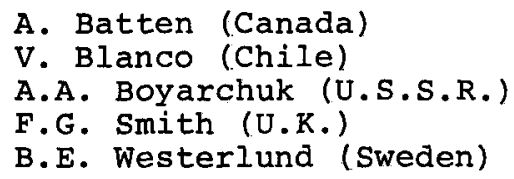

This list was unanimously approved by the General Assembly. 
15. Proposal for Resolution presented by the Executive Committee

The President announced that this item refers to the change of Statute 18 as read at the First Session of the General Assembly and as supported in the report of the Finance committee. The text, in French, is as follows:

L'article 18 (a) des Statuts, tel qu'il apparât dans les Transactions de l'UAI vol. XIV B, soit reformulé comme suit:

18 (a) Pour chaque Assemblée Générale ordinaire, le comité Exécutif prépare un projet de budget pour la période à courir jusqu'à l'Assemblée Générale ordinaire suivante, ainsi que les comptes de l'Union pour la période précédente. Il les soumet au Comité des Finances pour examen; ce Comité des Finances est composé de membres nommés par les organismes adhérents, à raison d'un membre par organisme, et il est approuvé par l'Assemblée Générale. Lors de sa première séance pendant l'Assemblée Générale, le Comité des Finances élit un Président parmi ses membres.

18 (b) Le Comité des Finances examine les comptes de l'Union pour voir si les dépenses engagées ont été conformes aux voeux émis lors de la précédente réunion de l'Assemblée Générale; il s'assure que le budget proposé vise à la poursuite de la politique de l'Assemblée Générale, telle qu'elle est interprétée par le Comité Exécutif. Il présente des rapports sur ces questions qu'il soumet a l'Assemblée Générale pour approbation des comptes, et pour décision sur le budget."

Les paragraphes (b), (c), (d) et (e) du présent article 18 des statuts deviennent les paragraphes (c), (d), (e) et (f) respectivement.

(See p. 15 for text in English)

He then put this motion to the vote of the General Assembly which carried it with one abstention, and no contrary vote.

16. Proposals for resolutions presented by Adhering Organizations

The General Secretary reported that the proposals for resolutions submitted to the General Assembly by Adhering Organizations and by Commissions had been passed to the Resolutions Committee for consideration. Before voting took place, Prof. F.G. Smith, Chairman of the Resolutions Committee, would present to the Assembly the Report of this Committee.

The President called upon Prof. Smith, who noted that Item 16 of the Agenda refers to Resolutions of National Committees as they are given under Item 10 of the Agenda of the First Session of the General Assembly.

The French National Committee, according to information before the Resolutions Committee, had withdrawn the lst and 2 nd motions of Item 10 (a), leaving only Item 10 (a) (iii) to be voted on at this Session. 
The President remarked that this question had been discussed by National Representatives at their meeting on 18 August at Estérel. He then put motion (iii) to the General Assembly. The motion was defeated by a substantial majority.

Professor Smith then referred to the motion proposed by the Swedish National Committee as given in Agenda Item 10 (b). This also, according to the Committee's information, had been withdrawn.

17. Proposals for resolutions proposed by IAU Commissions

At the request of the President, Professor F.G. Smith, Chairman of the Resolutions Committee, reported that proposals listed under Agenda Item 11 were considered by the Resolutions Committee together with all other resolutions proposed by Commissions. He reported further as follows:

The Resolutions Committee is required to assemble all the resolutions from Commissions and to present them in a suitable form at the Second Session of the General Assembly. This is a large task that must be carried out in a short time and it is impossible to consult Commission Presidents on the details of all resolutions. The Committee acted on two principles: first to restrict the number of resolutions to be adopted as IAU resolutions; and second, to publish, as far as possible, all the resolutions to be placed before the General Assembly, whether they are for adoption or merely to be noted. Publication was possible through the valuable co-operation of the editor of the Assembly newspaper METEORE, who arranged that the texts would be available on the morning of the Second Session, including a preliminary translation into French.

Resolutions for adoption at the General Assembly are those that either require specific IAU action or seem to be of wider interest than is implied by a Commission resolution. In the latter category, the Committee placed the resolution formerly listed under Agenda Item 11 (e). Also requiring adoption by the General Assembly are the resolutions concerning the organization of Commissions and their names.

The Chairman of the Resolutions Committee, Professor F. Graham Smith, presented the resolutions as follows:

RESOLUTION NO. 1

L'Assemblée Générale prend note du soutien des Commissions 4, 7, $8,19,20,24,25,26,33,36,37$ et 45 pour les programmes astrométriques indépendants et complémentaires proposés pour le

Satellite Astrométrique de l'ESA et le Téléscope Spatial de la NASA.

The General Assembly notes the support of Commissions 4,7, 8, 19, $20,24,25,26,33,36,37$, and 45 for the independent and complementary astrometric programmes proposed for the ESA Astrometry Satellite and the NASA Space Telescope.

(N.B. This resolution was the result of an amendment to the motion presented by Commission 24 in consequence of the proposal under Agenda Item II (e). The amendment was proposed by M.J. Seaton, supported by C.A. Murray, and adopted.) 
L'Union Astronomique Internationale

\section{Considérant}

a) La proposition originale de plusieurs pays en voie de développement de réaliser et de faire fonctionner, en collaboration, un Radiotélescope Equatorial Géant (GERT) en Afrique, près de l'équateur:

b) La possibilité pour GERT de fournir à des longueurs d'onde métriques des données de haute qualité comme complément essentiel aux données obtenues ailleurs en ondes centimétriques;

c) La remarquable utilisation d'un site équatorial pour obtenir une bonne résolution et une grande sensibilité;

d) Les avantages éducatifs, technologiques et sociaux attendus de la collaboration des pays engagés dans une recherche de pointe astronomique et spatiale:

Recommande que l'ICSU entreprenne des démarches pour obtenir le soutien de l'UNESCO dans la réalisation du Radiotélescope Equatorial Géant.

The International Astronomical Union

\section{Considering}

a) The imaginative proposal by several developing countries to construct and operate, in collaboration, a Giant Equatorial Radio Telescope (GERT) in Africa, near the equator;

b) the ability of GERT, operated at meter wavelengths, to provide high quality data as essential complement to data obtained elsewhere at $\mathrm{cm}$ wavelengths;

c) the noteworthy utilisation of an equatorial location for obtaining high resolution and sensitivity;

d) the educational, technological and social benefits expected for the collaborating nations involved in participation at the research front of astronomy and space science;

Recommends that the ICSU take steps to secure UNESCO support for the realisation of the Giant Equatorial Radio Telescope.

$$
\text { RESOLUTION No. } 3
$$

L'Union Astronomique Internationale

Considérant

a) l'apport que constituent pour l'humanité les resultats scientifiques obtenus par la Radioastronomie dans l'exploration de 1'Univers; 
b) I'utilisation croissante du domaine de fréquences radio surtout par les émetteurs embarqués;

c) que le CCIR a déterminé les niveaux d'intérference nuisibles dans son rapport CCIR 224-4;

d) que le CCIR et l'IUCAF ont résumé les besoins de la Radioastronomie dans divers rapports et documents;

e) que la "World Administrative Radio Conference" de 1979 (WARC) allouera des fréquences radio dont on peut espérer qu'elles seront maintenues pendant environ 20 ans;

Recommande que les administrations adhérentes à l'UAI présentes à la Conference WARC, reconnaissent les besoins suivants pour la Radioastronomie:

1) L'obtention et/ou le maintien de bandes de fréquences ayant des largeurs de bande d'au moins $1-2 \%$ a des intervalles d'environ une octave dans le spectre radio.

2) L'obtention et/ou le maintien de bandes plus étroites aux fréquences des raies spectrales les plus importantes en Astrophysique, avec des largeurs de bande appropriees pour la recherche scientifique.

3) La preservation de ces bandes de frequences de toute interférence nuisible provenant d'emissions dans la bande, en bord de bande, ou hors bande.

The International Astronomical Union

\section{Considering}

a) The value to mankind of the scientific results achieved by radio astronomy through the exploration of the universe;

b) the increasing use of the radio spectrum, especially by space and air-borne transmitters;

c) that the CCIR had specified the levels of harmful radio interference in CCIR Report 224-4;

d) that the CCIR and IUCAF have summarized the needs of the radio astronomy service in their various reports and documents;

e) that the 1979 World Administrative Radio Conference (WARC) will allocate radio frequencies which can be expected to remain in force for about 20 years;

Recommends that administrations adhering to the IAU, present at the WARC, recognize the following needs of the radio astronomy service:

1. The acquisition and/or maintenance of frequency bands with bandwidths of at least 1-2 per cent at approximately octave intervals throughout the radio spectrum. 
2. The acquisition and/or maintenance of narrower bands at frequencies of the astrophysically most important spectral lines having bandwidths appropriate to the scientific investigation.

3. The preservation of these frequency bands free of harmful interference from in-band, band-edge, and out-of-band transmissions.

$$
\text { RESOLUTION No. } 4
$$

L'Assemblée Générale approuve les recommandations des Commissions 16 et 17 que la Commission 16 (Etude Physique des Planètes et des Satellites) et la Commission 17 (La Lune) fusionnent pour former une nouvelle commission qui conserve le titre et le numéro de la Commission 16.

The General Assembly approves the recommendations of Commissions 16 and 17 that Commission 16 (Physical Study of Planets and Satellites) and Commission 17 (The Moon) be merged to form a new Commission, retaining the title and number of Commission 16.

$$
\text { RESOLUTION No. } 5
$$

L'Assemblée Générale approuve les changements suivants dans le

\begin{tabular}{|c|c|c|c|}
\hline Comm. & 5 & $\begin{array}{r}\mathrm{de} \\
\mathrm{a}\end{array}$ & $\begin{array}{l}\text { Documentation } \\
\text { Documentation et Données Astrono- } \\
\text { miques }\end{array}$ \\
\hline Comm. & 14 & de & $\begin{array}{l}\text { Données Spectroscopiques Fondamen- } \\
\text { tales } \\
\text { Données Atomiques et Moléculaires }\end{array}$ \\
\hline Comm. & 44 & $\mathrm{de}$ & $\begin{array}{l}\text { Observations Astronomiques au-dehors } \\
\text { de l'Atmosphêre Terrestre } \\
\text { l'Astronomie à partir de l'Espace }\end{array}$ \\
\hline Comm. & 45 & de & $\begin{array}{l}\text { Classifications Spectrales et In- } \\
\text { dices de Couleur à Plusieurs Bandes } \\
\text { Classification Stellaire }\end{array}$ \\
\hline
\end{tabular}
nom des Commissions:

The General Assembly approves the following changes in the names

\begin{tabular}{|c|c|c|c|}
\hline Comm. & 5 & $\begin{array}{r}\text { from } \\
\text { to }\end{array}$ & $\begin{array}{l}\text { Documentation } \\
\text { Documentation and Astronomical Data }\end{array}$ \\
\hline Comm. & 14 & $\begin{array}{r}\text { from } \\
\text { to }\end{array}$ & $\begin{array}{l}\text { Fundamental Spectroscopic Data } \\
\text { Atomic and Molecular Data }\end{array}$ \\
\hline Comm. & 44 & $\begin{array}{l}\text { from } \\
\text { to }\end{array}$ & $\begin{array}{l}\text { Astronomical Observations from } \\
\text { Outside the Terrestrial Atmosphere } \\
\text { Astronomy from Space }\end{array}$ \\
\hline Comm. & 45 & $\begin{array}{l}\text { from } \\
\text { to }\end{array}$ & $\begin{array}{l}\text { Spectral Classification and Multi- } \\
\text { band Colour Indices } \\
\text { Stellar Classification }\end{array}$ \\
\hline
\end{tabular}
of Commissions: 
Each of the resolutions listed above for adoption by the General Assembly was so adopted.

Professor Smith, continuing the Report of the Resolutions Committee, invited the General Assembly to note the following Commission Resolutions:

Commission 4

recognizing (a) that timings of occultations of stars by the Moon will continue to be of value in studies of the lunar motion and figure, the rotation of the Earth, and the stellar reference frame, and

(b) that it is desirable that the observations should continue to be collected and processed by one organization,

considering that, beginning with January 1981, HM Nautical Almanac Office, Royal Greenwich Observatory, will no longer be able to act as the international centre for the receipt and processing of timings of occultations,

recommends that an organization with the appropriate experience and commitment to the occlitation programme be requested to take over this important work.

Commission 4

expresses its full support in favour of the proposal of the Space Research Center of the Polish Academy of Sciences, and the Smithsonian Astrophysical Observatory to convene the Second International Colloquium on Reference Systems for Earth Dynamics.

Commissions $4,8,19$ and 31 endorse the recommendations given in the Report of the Working Group on Nutation, as set out below, and recommend that they shall be used in the national and international ephemerides for the years 1984 onwards, and in all other relevant astronomical work.

Recommendations of the Working Group on Nutation

Whereas the complete theory of the general nutational motion of the Earth about its centre of mass may be described as the sum of two components, (i) astronomical nutation, commonly referred to as nutation, which is motion with respect to a space-fixed coordinate system, and (ii) polar motion, which is motion with respect to a body-fixed coordinate system, it is recommended that: 
(a) astronomical nutation be computed for the "Celestial Ephemeris Pole" using a non-rigid model of the Earth such that there are no nearly diurnal motions of this celestial pole with respect to either spacefixed or body-fixed coordinates, which can be calculated from torques external to the Earth and its atmosphere.

(b) the numerical values given in Table 1 of the complete report be used for computing astronomical nutation of the "Celestial Ephemeris pole".

(4)

Commissions 4,19 and 31

considering that it is planned to introduce the IAU (1976) system of Astronomical Constants, the IAU (1979) Theory of Nutation, and the equinox of the FK5 on 1984 January 1 ,

recommend that (a) the relationship between mean sidereal time and UTl be modified so that there is no change in either value or rate of UTl, due to a correction to the zero point of right ascensions of the FK4 and to a correction for the motion of the zero point, to be introäuced in FK5

(b) the new (provisional) expression for Greenwich mean sidereal time of oh $^{\text {UT }}$ be -

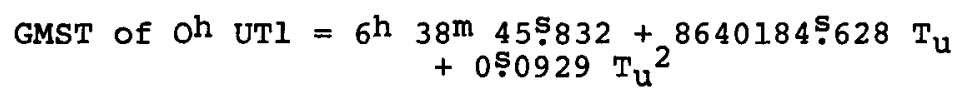

where $T_{u}$ is the number of Julian centuries of 36525 days of Universal Time elapsed since 1900 January 0, $12^{\mathrm{h}}$ UTl (JD 2415020.0 ). This expression is rigorously equivalent to the following:

GMST of $0^{\mathrm{h}}$ UTl $=6^{\mathrm{h}} 4 \mathrm{IT}^{\mathrm{m}} 50 \mathrm{~S} 5529+8640184 \$ 8138 \mathrm{Tu}$
$+0 \$ 0929 \mathrm{~T}_{\mathrm{u}}^{2}$ where $\mathrm{T}_{\mathrm{u}}$ is measured from 2000 January $1,12^{\mathrm{h}}$ UTl (JD 2451545.0).

(5)

Commissions 4,19 and 31

endorse the proposal of the joint working group on the determination of the rotation of the Earth for a special period of international collaboration in the monitoring of Earth-rotation and in the intercomparison of the techniques of observation and analysis,

recognize that the responsibility for the organization of this Project MERIT should be shared with the International Union of Geodesy and Geophysics, and

request that the national and international organizations 
concerned give full technical and financial support to the development of the proposal and to the implementation of the project.

(6)

Commissions 4 and 16

endorse the Report of the Joint Working Group on Cartographic Coordinates and Rotational Elements of the Planets and Satellites,

recommend that the Report be used as the basis for computing the physical ephemerides of planets and satellites in the international and national ephemerides, and

request

that a small working group continues its activity in order to provide improved rotational elements.

Commission 5

considering the steadily increasing number of publications in the field of Astronomy and Astrophysics,

recommends the introduction and extensive use of proper key words by authors and publishers of primary journals and other publications in order to facilitate indexing and retrieval work,

welcomes the initiative of Astronomical and Astrophysical $\mathrm{Ab}-$ stracts (AAA) in preparing a draft vocabulary, and

invites AAA and other astronomical abstracting services to cooperate in the preparation of an agreed vocabulary.

Commission 5

considering the present unsatisfactory situation of the identification of astronomical objects in astronomical publications,

supported by representatives of Commissions $8,24,25,26,27,28$, $29,30,34,37,40,42$, and 45 ,

requests strongly that

(a) editors of scientific journals and other publications impose stricter standards of object indentification upon the authors through appropriate instructions to referees,

(b) catalog abbreviations be made explicit either in footnotes or in the bibliography tables 
(c) two identifications be quoted for each object in order to provide a check against errors and misprints, especially for faint objects.

(9)

Commission 5

considering the confusion existing at the present time in the literature concerning the abbreviations of catalogues,

supported by representatives of Commissions $8,24,25,26,27,28$, $29,30,34,37,40,42$, and 45 ,

desires that, under IAU auspices, a list of catalogue abbreviations be published. This list should be a new version of the work of Fernandez, Lortet and spite, revised by IAU Commission representatives and edited by $C$. Jaschek.

Commission 10

recognising that the International Ursigram and World Days Service (IUWDS) has rendered valuable service to the scientific community during the coordination of such international programs as the IGY, the IQSY and the IMS,

that the services provided by the IUWDS are not provided by any other agency and are relevant to the work of several IAU Commissions,

that these services will be particularly important for such programs as the Solar Maximum Year,

and that the IUWDS includes the prompt reporting of geophysical and solar events which will be occuring with increased frequency in the next few years,

recommends that the IAU continue to support the activities of the IUWDS to ensure the continuance of this valuable service.

Commission 10

recognizing that the long series of Relative Sunspot Numbers is a unique link with the course of solar activity in the past

recommends that all institutions that have demonstrated interest and competence in the work of obtaining sunspot numbers should continue the series. 
Commission 10

recognizing that the Quarterly Bulletin of Solar Activity has for many years provided a valuable reporting service to the international scientific community,

that this service continues to be relevant to the activities of Commissions $10,12,40,44$, and 49 of the IAU,

that the continuation of this service will be of particular value during the coming Solar Maximum Year,

recommends

that the IAU support the Quarterly Bulletin of Solar Activity to ensure that this service continue into the future.

Commission 10

recognizing that the $2800 \mathrm{MHz}$ solar flux provides a standard quantitative index of solar activity for use in solar and solar-terrestrial studies,

recommends that those institutions making such measurements should continue to do so.

Commission 10

recognizing the important contribution made to solar physics by very high frequency (greater than $9 \mathrm{GHz}$ ) radio flux observations of the sun,

recommends that such observations should continue to be strongly supported during the coming solar maximum.

Commissions 10,12 , and 44

draw attention to the coming of solar Maximum and recommend a sustained and coordinated effort in its study during the next three years.

Commissions $15,20,21$, and 22

recognizing the major significance of comets for the study of the origin and evolution of the solar system in general and the interplanetary solid material in particular, 
noting the extreme diversity among individual comets in terms of composition, structure, and physical behaviour, and

conceding that ground-based observations are largely inadequate for establishing unequivocally the nature of the relationship between comets and other objects in the solar system,

recommend that a vigourous programme of space exploration of comets be initiated. To ensure the maximum science return, the programme should include more than one comet and should include fly-by, rendez-vous and, ultimately, sample-return missions. A rendez-vous mission to $\mathrm{P} /$ Temple 2 in 1988 with an en-route flyby of P/Halley in 1985, currently considered by NASA, is regarded as an ideal first step in the programme.

\section{Commissions 25 and 45}

noting the strong support of 12 IAU Commissions for space astrometric programs,

recommends that complementary ground-based support in astrometry, photometry, spectroscopy, etc. should be encouraged.

Commission 26 notes with deep concern that the sproul observatory is in danger of being closed by Swarthmore College. The termination of the astrometric program would cut off a highly productive source of double star data built up over a long period of time. The photographic plate collection with its continuing growth from the Sproul refractor is unique and continues to yield valuable results.

Commission 30

considering the need for optimum combination of independent series of data

recommends that the publication of new radial velocity measurements should be accompanied by the following essential information:

1. For each Series of measurements -

Description (or reference to published description) of the instrument characteristics, i.e., measuring principle, resolution, detector, etc.

Measuring technique (for plates)

Stellar lines employed and adopted wavelengths 
Average number of lines measured

Measured velocities of IAU standard stars

Period of Observation

2. For each star or other object -

Preferably: individual velocity measures

individual times of obervation

mean radial velocity

weighting procedure

external mean error estimated

Minimum: mean radial velocity

period of observation

number of measurements

external mean error estimated

Any previous measurements used in the mean should be clearly identified.

The star should be unambiguously identified, either by catalogue number (catalogues in order of priority recommended by Commission 5), or by precise position (error 1 2 arcsec.), 으, if necessary, by a finding chart.

(20)

Commission 31

considerant a) que le temps Atomique International, TAI, est établi par le BIH d'apres les donnees fournies par plusieurs laboratoires où fonctionnent les horloges et etalons de frequence independants

et b) que des donnees d'autres laboratoires, nécessaires pour ameliorer le TAI, ne peuvent pas etre utilisees car les liaisons horaires internationales existantes ne conviennent pas,

recommande a) que les laboratoires qui s'occupent du temps et des fréquences en Extreme Orient et Asie, en Afrique, en Australie et en Amerique du Sud, établissent des liaisons horaires internationales de grande exactitude

et b) qu'une aide leur soit apportee par les organismes nationaux et internationaux pour qu'ils puissent utiliser des techniques de grande précision, telles que celles qui impliquent l'usage du LORAN-C, des horloges transportables, des satellites artificiels de la terre, et de l'interférométrie à très longue base.

(21)

Commission 37

recommends that the designation of star clusters within the 
Galaxy should be based on the equatorial coordinates (1950.0), prefixed by the letter $C$. The right ascension element should consist of hours and minutes of time ( 4 digits) and the declination element by the algebraic sign, followed by degrees and one decimal ( 3 digits). In both quantities appropriate leading zeros should be inserted. Once a designation has been assigned to a particular cluster it should not be changed, even if later investigations indicate that the coordinates used in the designation differ from the centre of the cluster.

Commission 44

takes note of the growing interest in 1-m. class space Schmidt telescopes and encourages members of the IAU to make their interests known to the Chairman of the Working Group for Surveys from Space in Commission 28 .

Commission 44

notes with interest, and encourages participation in, the various efforts to coordinate observations of the Sun near its activity maximum such as the Meudon Flare Buildup Study and the NASA Solar Maximum Mission.

Whereas the IAU supports the organisation of Regional Astronomy Meetings," Commission 46 recommends that the IAU urge the holding of sessions on teaching of astronomy at these meetings. Members of Commission 46 are available to assist.

Professor Smith noted, also, that the proposals implicit in items 11 (a) and 11 (c) of the Agenda were responded to in the Budget 1980-82, accepted by the General Assembly.

Professor Smith concluded by noting that a Working Group on the nomenclature of features of solar system bodies (WGPSN) had presented a Report, approved by the Executive Committee and by the Resolutions Committee. This Report now becomes an official document of the IAU.

18. Membership

a) Admission of Indonesia to the IAU

The General Secretary referred to her narrative report presented at the First Session. She reaffirmed that the Executive Committee had carefully examined the application of Indonesia for admission as an Adhering Country to the Union and that it had found that the degree of astronomical development in that country met the standards required for IAU Membership. The General secretary there- 
fore moved that the General Assembly admit Indonesia as a new Adhering Country. This motion was adopted unanimously.

The President invited Dr. B. Hidayat, the official representative of Indonesia, to be seated among the representatives of Adhering Countries. Dr. Hidayat then took the floor, expressed his thanks to the General Assembly for having admitted Indonesia to the IAU, and emphasized that Indonesia would spare no effort to promote astronomical cooperation throughout the world.

b) The President presented to the General Assembly the following report concerning the restoration of the Membership in the IAU of the Democratic People's Republic of China as follows:

The President reported as follows: At the first session of this General Assembly I have informed you about correspondence and discussions leading to the presence among us of chinese colleagues from all parts of China, giving us opportunity to further work out arrangements for the formal adherence to the Union. What has been achieved up till now?

National representatives have been kept fully informed on the proceedings during the past few days and have been given copies of the following documentation: (a) an exchange of letters dated August 22 between the president of the Chinese Astronomical Soctety, Prof. Y.C. Chang of Purple Mountain Observatory, and myself as president of IAU; and (b) a draft for a resolution to be submitted to this General Assembly. In this letter, Prof. Chang in accordance with what we agreed upon, proposes that for the time being the full membership of China be established through dual adherence, with two adhering bodies: one being the Chinese Astronomical society which has its seat at Nanking, and one representing the astronomical community of Taiwan, the name for which has not yet been filled in. It is furthermore proposed that for the time being at our General Assemblies each of these two adhering organizations appoint its own delegate and that the total financial contribution of China will consist of two components, one for each of these two adhering organizations. As to the voting power of the two delegates, in accordance with our statutes (article VII, II) these will be of equal weight and the same as those of all other adhering organizations as far as administrative and scientific matters are concerned, whereas for budget matters the weight will be determined by the financial contributions according to the established system. Thus, the only point left open for final settlement of the full participation is the choice of the name for the adhering organization for Taiwan. In my letter of acknowledgement to Prof. Chang I have expressed the great satisfaction with which the Executive Committee has taken note of this proposal, and assured Prof. Chang of our readiness to take up this question of the missing name and our intention to do so in the near future, in consultation with the astronomical community of Taiwan and the Astronomical. Society at Nanking.

Thus, whereas we cannot say that at this moment the full membership of China has been restored, we consider that considerable progress has been achieved and we have good hopes that the completion is forthcoming. 
What I consider as one of our main accomplishments, is the fact that during these meetings at Montreal our Chinese colleagues and we have, after many years, again mutually benefited from their participation at our scientific discussions - and the prospect of continuation of this participation at our forthcoming symposia and other IAU meetings.

You may wonder why it is that the final settlement of the full membership had to be left pending, with only the question of a name to be filled in. Let me therefore explain that it is in this matter that we touch upon principles of general policy of the government authorities in these two geographical areas of China, which set limits to the range of possible names considered acceptable to all parties. We did not consider it proper to restore the full participation of China with the name of one of its adhering organizations still pending; and this the more so, now that we have full confidence that this question will be resolved soon when possibilities for solutions will be further explored after this Assembly.

This brings me to the resolution submitted to you on behalf of the Executive Committee. Its purpose is, to allow the Executive Committee to fully implement the full membership of China once the question of the name has been settled - possibly already before the end of this year. It would be a great pity if the full membership could become effective only at the next General Assembly. The resolution reads as follows:

"The General Assembly, of China;

in view of the reported progress in restoring full adherence

noting the letters on this subject exchanged between the President of the IAU and the President of the Chinese Astronomical Society, Prof. Y.C. Chang;

authorizes the Executive Committee to implement the anticipated conclusion of the current negotiations subject to ratification by the General Assembly at its next meeting."

This resolution then was submitted to the General Assembly and carried unanimously.

The President then continued as follows: Before we proceed to the next item of our agenda, I would like to express my deep gratitude to all our colleagues through whose, sometimes very considerable, effort we have been able to reach this point. It could not have been so without the fully cooperative spirit that, from the outset, has characterized the contributions to our discussions from both the astronomical communities, of the main-land of China and of Taiwan. It would have been impossible without the presence here at Montreal of the delegation of the Chinese Astronomical Society, and with regard to the delegation from Taiwan, may I express my deep admiration for the untiring effort by which its representative, Prof. C.S. Shen, has contributed to this purpose. And may I remind you also how much we owe to the many other colleagues who, not only during this Assembly but already during the preceding 
years, have helped so much by paving the road that has led to the present result.

Finally, would the representative from Taiwan care to say a few words at this moment?

C. S. Shen: (abstract only):

The mainland Chinese astronomers have been absent from the IAU for almost twenty years. Many attempts have been made to restore their membership, particularly during the past ten days. Many of our colleagues must be wondering why this task is still not accomplished. As the representative of an adhering organization, I would like to offer a few words on this matter:

Let me first point out that the astronomers and authorities on the island of Taiwan have never opposed the re-joining of mainland China to the IAU. In fact we have done our best, in co-operation with the officers of the IAU, especially with Professor Blaauw, to facilitate their re-joining. We have repeatedly stated (orally and in writing) that the Chinese Astronomical Society located at Taipei represents the scientific community in the geographical area of Taiwan. We do not pretend and have never claimed to represent the scientific activities in mainland China...

At present, there exists a significant gap between the two parts of China, not only in the style of living, but also in the political and economic structures that form the foundations of the two parts. Peking is trying to claim Taiwan as a province of the People's Republic of China and to imply that the authorities in Taipei are subordinate to those in peking, and hence that the Nanking organization is a national one, while that in Taipei is regional. Taiwan is doing everything to avoid such an implication.

Of course, one has to be realistic. Mainland China has 900 million people with a potentially great astronomical community. They are our fellow Chinese; that is why we are doing what we can to solve the problem; however, we cannot accept a mode of adherence with semantic implications of a regional flavour vis-a-vis the name of the adhering body of mainland china. We represent an independent scientific community.

One need, however, not be too pessimistic about the China issue. It will usually be found that policies change if results cannot be achieved. Let us hope that well before the next General Assembly we shall have our fellow society from Nanking join us with due respect for the principle of equality of membership.

c) New Individual Members of the IAU

The General Secretary announced that the Executive Committee had, on the proposal of the Adhering Bodies and with the advice of the Nominating Committee, admitted 780 new Members to the Union and deleted 36 Members from its Membership List. The names of the new Members had been displayed in a prominent place in the course of the General Assembly. The General secretary informed the General Assembly that these names would be incorporated in the Alphabetical List of IAU Members to appear in Transactions, Volume XVIIB. 
The President then congratulated the new Members on their election and expressed his hope that their cooperation with and within the Union would be pleasant and fruitful.

19. Commission Presidents and Vice-Presidents

The General Secretary presented, on behalf of the Executive Committee, the following list of Presidents and Vice-Presidents of IAU Commissions for election by the General Assembly:

$$
\begin{aligned}
& \text { No. } \\
& 4 \text { Commission Name } \\
& 5 \quad \begin{array}{l}
\text { Documentation and As- } \\
\text { tronomical Data }
\end{array}
\end{aligned}
$$

6. Astronomical Telegrams

7. Celestial Mechanics

8. Positional Astronomy

9. Astronomical Instruments

10. Solar Activity

12. Radiation and structure of the Solar Atmosphere $Y$. Uchida

14. Atomic and Molecular Data J.G. Phillips

15. Physical study of Comets Minor Planets and Meteorites

16. Physical Study of Planets and Satelitites

19. Rotation of the Earth

20. Positions and Motions of Minor Planets, Comets and Satellites

21. The Light of the Night Sky

22. Meteors and Interplanetary Dust

24. Photographic Astrometry

25. Stellar Photometry and Polarimetry

26. Double Stars

27. Variable Stars

28. Galaxies

29. Stellar Spectra

30. Radial Velocities

31. Time
B. Donn

President

$$
\text { A.M. Sinzi }
$$

W.D. Heintz

J. Hers

Y. Kozai

E. $H \phi g$

E.H. Richardson

V. Bumba

B.A. Smith

P. Pâquet

G. Sitarski

H. Tanabe

W.G. El ford

H.K. Eichhorn

J.A. Graham

O.G. Franz

J.D. Fernie

B.E. Westerlund

W.K. Bonsack

M. Duflot

s. Iijima
Vice-President

T. Lederle

G.A. Wilkins

M.P. Candy

J. Kovalevsky

K.N. Tavastsherna

W.C. Iivingston

E. Tandberg-Hanssen

R.W. Noyes

A.H. Gabriel

B.J. Levin and

C. Chapman

V.G. Teifel

Ya. S. Yatskiv

E. Roemer

R.H. Giese

O.I. Belkovich

w. Gliese

J. Tinbergen

M. Fracastoro

N.H. Baker

Vera Rubin

J. Jugaku

A.G.D. Philip

G. Hemmleb 
№. Commission Name

$\underline{\text { President }}$

Vice-President

33. The structure and Dynamics

of the Galactic System G.G. Kuzmin R. Wielen

34. Interstellar Matter and Planetary Nebulae

V. Radhakrishnan M. Peimbert

35. Stellar Constitution

R.J. Tayler A.N. Cox

36. The Theory of Stellar Atmosphere

G. Traving

B. Gustafsson

37. Star Clusters and Associations

G. Lynga

K.C. Freeman

38. Exchange of Astronomers

J. Delhaye

F.B. Wood

40. Radio Astronomy

G. Swarup

K.I. Kellermann

41. History of Astronomy

M.A. Hoskin

o. Pedersen

42. Close Binary Stars

B. Warner

A.H. Batten

44. Astronomy from space

R. Van Duinen

M. Oda

45. Stellar Classification

A. Slettebak

V.L. Straizys

46. The Teaching of Astronomy

D.G. Wentzel

L. Houziaux and

M. Rigutti

47. Cosmology

G.0. Abell

J. Audouze

48. High Energy Astrophysics F. Pacini

49. The Interplanetary Plasma

and The Heliosphere H.J. Fahr

I.W. Roxburgh

50. Protection of Existing and Potential Observatory Sites

F.G. Smith

A.A. Hoag

This list was approved by the General Assembly.

The slates of the Organizing Committees of IAU Commissions, as approved by the Executive Committee, were projected on a screen. The General secretary announced that the composition of Commissions, general members included, would be published in IAU Transactions Vol. XVIIB.

20. Place and Date of the XVIIIth General Assembly

Called upon by the President, the General secretary announced that there was no invitation by an Adhering Country before the General Assembly to host the XVIIIth General Assembly of the IAU in 1982. The place and date of the next ordinary General Assembly will therefore have to be determined by the Executive Committee and communicated to Adhering Bodies. Under consideration are the following countries: Greece or USA for 1982 and Spain for 1983.

21. Election of the New Executive Committee

The General Assembly approved by acclamation the formal proposal of the President that Prof. M.K.V. Bappu be elected the new President of the Union for the term 1979-1982. 
The President then moved that Dr. M.W. Feast, Dr. I. Kresak and Prof. R. Wilson be elected Vice-Presidents for the term 1979-1985. This motion was approved by acclamation.

The President continued by proposing that Prof. P.A. Wayman be elected General Secretary for the Union and Dr. R.M. West be elected Assistant General Secretary of the Union for the term 19791982. This proposal was also approved by acclamation. The President then invited Prof. Bappu, Dr. Feast, Dr. Kresak, Prof. Wilson and Dr. West to join the Executive Committee on the platform.

22. Addresses by the retiring and newly elected officers

The retiring President, Prof. Adriaan Blaauw spoke as follows:

We now approach the conclusion of the administrative part of this, 17th, General Assembly, and in a few minutes I shall call on the newly elected President; however, before doing so I wish to express my sincere thanks to my colleagues on the Executive Committee with whom I had the privilege to work during these three years - colleagues who thereby have become even closer friends than they were before.

I first want to thank the now outgoing vice presidents, John Bolton, Charles Fehrenbach and Wilhelmina Iwanowska for their fine contributions, and hope that there will be many occasions where we will meet again and further enjoy this friendship. We are very sad that John Bolton could not be with us these days. I am sure I will speak on behalf of all of us if, after this meeting, I write to him to tell him how very much his devotion to the affairs of the Union has been appreciated.

I also wish to thank the outgoing adyisors, Leo Goldberg and George Contopoulos, for the way they have let us benefit from their rich experience in matters of the I.A.U. Their leaving the Executive Committee means a great loss to the built-in wisdom of the committee, but we trust it will remain available if we ever need it again.

It has been said before that it is the General Secretariat where the heart of our Union beats. We all, members of the Union, know with how much care the secretariat handles its many-fold affairs. Now that its crew, too will be leaving us, we have the oppurtunity to express our deep felt thanks for all you, Edith Müller, Arnost Jappel and Jarka Dankova have done for the IAU. Many of us have often wondered how you, Edith, could manage to do so many things - not only for the IAU but also in your many other obligations - and do them with such intensity, combining your scientific interests with your wonderful devotion to, and experience in, our Union. To express it in terms of an observational astronomer, you have shown a dynamic range that many of us envy! We will continue to benefit from it in your new, but more relaxed, position as advisor to the Executive Committee.

Edith will be succeeded by Patrick Wayman, an appointment that assures us that the affairs of the Union are in the best possible hands. It is not only the experience and knowledge gained in the specific task of the Assistant General secretariat, the planning 
of colloquia, symposia and other meetings which Patrick Wayman has performed so admirably, but also the way he has already been involved in other important current affairs of the union and his broad administrative experience that make him eminently suitable for this task.

May I suggest that the General Assembly show its appreciation for the IAU's Secretariat in the usual way?

At the request of Professor Blaauw, the newly elected President, Prof. M.K.V. Bappu, addressed the General Assembly:

Professor Blaauw, Members of the Union, Ladies and Gentlemen,

I would like to express my deep appreciation of the great honour you have done me by electing me President of the Union for the next three year term. At this moment, a twin emotive feeling of gratitude and responsibility overwhelms me; gratitude at the trust and confidence you have displayed by choosing me for this high office on which so many of my eminent predecessors have added lustre, and a feeling of great responsibility in a realization of the implications of this trust. That it is an union of astronomers makes the task lighter, for the astronomical fraternity is a brotherhood that unites men and takes them above the little world of nationalism into a truly international beyond. And when, to it, we add the extremely pleasant prospect of the continued availability of your wisdom, experience and counsel, Prof. Blaauw, I am sure that we face the future with serene confidence. The manner in which you have steered the Union through the occasional troubled waters of a world with political affinities, demands our admiration and gratitude. You have led a splendid team of dedicated individuals; to all the members of the Executive committee, the Union is very deeply indebted, and especially to its charming and efficient General Secretary, Prof. Edith Müller, who has continued in the distinguished tradition of performance of General secretaries of the past.

The last decade and more have witnessed spectacular happenings of fruitful work in new spectral domains, major strides of technological progress and great achievements by individuals and groups of individuals, both in theory and in observation. This dynamic state of affairs, of expanded horizons and activity, has brought along a manifold increase in the number of active astronomers. An increase in size of our Union is natural and inevitable; our only concern need be to ensure that we permit ourselves an adaptability of methodology and procedure whereby we can fulfill the aims of the Union. An increased reliance on symposia, more regional meetings that have the international flavour of a General Assembly, the fostering of an enlarged programme of exchange of astronomers between astronomical institutions - these are some measures we have already taken, and which, in the years to come, will hopefully justify the faith we have placed in them. Our decisions in this regard need to be tempered by a recognition of the fact that meetings of the General Assembly serve a twofold requirement. Besides being occasions when we recount the accomplishments of the past three years and project and formulate new plans for the future, perhaps the most important aspect is the opportunity provided for personal contracts and discussion between members of all ages. 
The progress made by our science is a saga of accomplishments by the different individuals who make up the Union membership; it should, therefore, be the Union's utmost concern to see that opportunities for such stimulation and inspiration are plentiful.

It is a gratifying trend to witness an increase in membership of countries. We have come a long way from the initial seven who adhered to the Union in its first year of existence. This tendency heartens us, for we have a high opinion of our science and would like many others to share our enthusiasm for exploration of the Universe. And as each member, individual and country, contributes stone by stone to the vast edifice of astronomical knowledge, we rejoice without reservation and in all friendliness at the triumph of the human mind over a facet of Nature. In encouraging opportunities and providing that little extra fillip needed to cross the threshold into the domain of creative productivity, the Union can play an important role.

These are some thoughts that come to mind and which I would like to share with you. With your abundant goodwill and cooperation, my colleagues on the Executive Committee and I approach these possibilities with much optimism. May the International Astronomical Union, in the years ahead, continue to be a source of strength to astronomy and to astronomers.

\section{Closing Ceremonies}

Prof. Blaauw then invited Prof. Ch. Fehrenbach to propose a comprehensive vote of thanks.

Chers amis Canadiens,

Vous etes presqu'au terme de votre peine. Mais nous savons que lorsque les invites sont partis, apres un moment de soulagement et de satisfaction lorsque tout s'est bien passe, il reste a ranger et la salle a manger et le salon et il faut quelque temps pour que tout redevienne normal.

Au nom du Comite Executif et de tous les astronomes j'ai le grand plaisir de vous adresser nos vifs remerciements pour la facon dont vous avez préparé et mené cette grande Assemblée Générale qui a réuni plus de 2000 astronomes et 1000 de leurs invités.

Votre organisation a ete parfaite a tous points de vue a la fois pour la teneur des rénions plenieres a l'Université ou dans les diverses grandes salles de la ville. Vous nous avez toujours accueilli avec le sourire et vous avez resolu tous nos problemes.

Le seul que j'ai eu personnellement etait celui de la decouverte des salles dans l'Universite. Mais à la fin, j'ai appris qu'on pouvait atteindre le bureau du president en prenant l'ascenseur situe pres des cubicules des etudiants avances, dont le sens m'echappe sinon sa relation avec l'ascenseur. D'ailleurs une de vos hautes autorités m'a confie la façon expeditive de faire passer les examens à vos étudiants: vous leur donez rendez-vous à une salle numerotee et ceux qui sont assez chanceux pour trouver la salle sont automatiquement recus. 
Excusez-moi si je vous "charrie" un peu, vous devez aussi utiliser ce mot pour plaisanter.

Je dois maintenant remercier d'abord le Comite d'organisation Canadien, qui sous la présidence de notre ami Alan Batten a eu la fonction essentielle d'obtenir le concours des autorités canadiennes. Et son succès a eté complet. Grâce au Conseil National de la Recherche du Canada, au Ministre de l'Education du Canada, de la Cité de Montréal et de nombreuses societés commerciales privées, grâce à l'aide des societés astronomiques Canadiennes de nombreuses contributions materielles ou en argent ont été obtenues. Et de nombreux jeunes astronomes ont pu recevoir des subventions de l'Union Astronomique, augmentées par vos fonds. Nous devons spécialement remercier la Municipalité de Montréal et son maire M. Drapeau qui a mis la salle des Arts à notre disposition et qui nous a offert l'excellent dejeûner qui a suivi la cerémonie Inaugurale.

Les intermèdes musicaux de très haute qualité de l'ensemble Claude Gervaise ont eté très applaudis.

Nous devons spécialement remercier Monsieur le Recteur de l'Université, representé en son absence par le Vice-Recteur, M. Rene Lévesque, pour toutes les facilites mises à notre disposition dans l'unite de Physique notamment, et je remercie le directeur de cette unite.

Je dois, et je le fais avec grand plaisir, remercier le comité Local préside par notre collegue $G$. Beaudet. En le remerciant personnellement je remercie aussi les secrétaires des deux Comités, Mlle Bergevin et Mlle Guibault. Le Dr Michaud, Mme Beaudet et tous ces aimables jeunes hommes et jeunes femmes qui nous ont tant facilité la vie.

Nous remercions aussi les personnes qui ont fait fonctionner la cafeteria, le bistrot et qui ont servi 37500 tasses de café. Les manifestations artistiques et culturelles ont été nombreuses. Je remercie particulierement le "Concept Neuf" qui nous a donné un récital de musique de percussion et Mme Monique Legrac pour son recital. Tous les concerts ont eté fort apprecies.

A la fin d'une assemblee de ce type on se pose toujours la question: est-elle un succès? C'est naturellement au succès scientifique qu'on pense d'abord, mais ce succès n'est pas possible si l'organisation n'est pas bonne a tous points de vue et si le sourire n'accompagne pas les petites difficultés de chaque jour.

Cette assemblee gênerale est un grand succès et, chers amis Canadiens, nous vous remercions pour votre excellente organisation, pour votre hospitalité, pour votre présence amicale à tous moments.

Un grand merci à tous, à ceux que j'ai cités, mais aussi à ceux, plus anonymes, qui les ont aide. Nous garderons un excellent souvenir de cette assemblée generale à Montréal, mais nous garderons le même excellent souvenir du beau pays que vous nous avez fait visiter dans des nombreuses excursions organisees a Montréal, dans les provinces de Québec et d'Ontario. Nous avons 
ete frappés par l'accueil si cordial et si souriant de tous les habitants de ce pays.

On behalf of the Registered Guests, Mrs Mavis Wayman expressed her thanks as follows:

Mr. President and Members of the Union, on behalf of all the guests at this General Assembly I would like to thank Mme Beaudet and her Committee for the wonderful way they have entertained us. Many thanks for the welcomes, starting at the guests' reception in Place des Arts, and continuing throughout the week in the hospitality room; also, their hard work in organizing a wide range of interesting tours for us is greatly appreciated. As hostesses, they did this beautiful city of Montreal proud. Please, Mme Beaudet, accept a small token of our appreciation for everything.

The president then called upon the retiring General Secretary, Professor Edith A. Miiller, who spoke as follows:

Dear Colleagues: - You may have read in one of the issues of METEOR that this evening I shall take a deep breath and then eclipse myself for a long vacation to clear my head from all administrative, organizational and diplomatic problems in order to get ready to resume my research work and my teaching duties with full strength. First of all I shall have to catch up with the recent astronomical literature and, thus, I look forward to learning about all the work you have done and the interesting results you have found. The past six years (three as Assistant General secretary, three as General Secretary) were for me very interesting, stimulating and, indeed full of hard work. Having attended many international meetings and visited numerous astronomical institutes in different countries, I had the opportunity of meeting many scientists and make a number of new friends. Though loaded with work the years serving the IAU were very enriching and enlightening for me.

My task as General Secretary was greatly facilitated by the kind support and advice $I$ received from our retiring President, Professor Adriaan Blaauw, from the members of the Executive Committee and from its Advisors. I wish to express here my sincere thanks to them.

In the IAU Secretariat I appreciated the cooperation of the long-standing IAU staff members Arnost Jappel and Jarka Dankova. Furthermore, I was fortunate to have been able to secure the devoted cooperation of two part-time secretaries: Mme Roswita Läubli who is here with us, and Mme Ruth Bertschi. To all four collaborators I owe my most cordial thanks for their devoted and efficient work. The IAU secretariat enjoyed the kind hospitality of the Astronomical Institute of the University of Lausanne, and it received substantial financial support from the Swiss Academy of Sciences through the National Committee of Astronomy, and from the Observatory of the University of Geneva. In the name and on behalf of the IAU, I thank the above-mentioned institutions for their great support. I also wish to express my gratitude to my colleagues both in Geneva and Lausanne for their moral aid and understanding and to my graduate students for their patience when 
pressing IAU affairs prevented me from attending immediately to their research problems.

I now wish to turn your attention to an important chapter in the history of the IAU and that of our two staff members, - a chapter which now is coming to an end. Arnost Jappel and Jarka Dankova have faithfully served several General Secretaries, - Arnost five, Jarka four General Secretaries, - moving every three years to another country with another language and other habits. Now they both will return to their home country, Czechoslovakia, Arnost Jappel starting his well deserved retirement, and Jarka Dankova resuming her work at the Czechoslovak Academy of Sciences. Arnost - with all the many interests you have, I am sure you will find yourself as busy in your retirement as before. Jarka - undoubtedly you will be happy to settle in your home country where you have your family and your friends and where you finally will feel "at home" again. To both of you the IAU and, in particular, the General Secretaries you served, express their most sincere thanks. Our best wishes accompany you in your future life and activities.

Our new General Secretary, Patrick Wayman, is to start a new chapter in the history of the IAU Secretariat. As I mentioned during the first session of this General Assembly, the IAU Secretariat will, from now on, function at its permanent seat in Paris, where a new secretary and a typist will be serving the General Secretary. Patrick - you have certainly a difficult task ahead of you by having to introduce two new staff members to the work of the IAU Secretariat, and by having to do much of this from a distance, - by some sort of a "remote control". I expect you will frequently commute between Dublin and Paris and, thus, become the "flying General Secretary". But I am sure you will handle everything most efficiently. I wish you much success.

The IAU is flourishing; - many fascinating fields of astronomical research have opened up and added exciting new results to our knowledge of the stars, the galaxies, the universe. A direct consequence of this is the rapid growth of the IAU. At the present General Assembly we are happy to welcome one new member country, Indonesia, and about 800 new Members. At this point I should remind you that proposals for new individual Members are primarily the responsibility of the National Committee of Astronomy of each member country. Evidently they are in a position to judge the competence and the scientific work and achievements of a proposed new Member. It would be a full-time job for the General secretary if he/she were to look into each individual case in detail.

Finally, with the future of the IAU in mind, I should like to sav a few words to the new Members of the IAU and also to all our Members. We are gathered here at a General Assembly, coming from different parts of the world, from countries with different governments, different cultures, different religions, - but we are all astronomers eager to learn more about the Universe and the objects which populate it. Let me remind you of our statutes which say that the IAU is a non-governmental, non-political organization whose objectives are a) to develop astronomy through international cooperation, b) to promote the study and development of astronomy in all its aspects, and c) to further and safeguard the interest 
of astronomy. Let the spirit of the IAU prevail in our minds and guide our work of international cooperation for the safeguard of astronomy and astronomers throughout the world.

Finally, the Chairman invited the newly elected General Secretary, Professor P.A. Wayman, to address the General Assembly. Professor Wayman spoke as follows:

Mr. President, members of the Executive Committee, fellow members of the Union,

We come from all continents and sub-continents to discuss what we love most - the science and practice of astronomy - and to enjoy, perhaps above all, the fellowship of astronomers across every kind of political and geographical divide.

Certain questions force themselves upon us at these times, as we prepare to leave our General Assembly. What does the Union mean to us? How will future ages regard our period?

We are indeed reaching a turning point, a watershed, in the affairs of the Union. Whatever problems lie ahead, we can be sure that a new era begins in 1979; new permanent staff, a new regime, with a permanent seat in the magically beautiful city of Paris. My message to IAU members on this occasion is - If you wish to make suggestions about how things should be done in the future, please write to me about it, in order to contribute to the evolution of the Union.

Arising from my work in the Union in the last three years I have some messages of thanks to convey.

I wish particularly to express admiration, in my recent experience, to the work of our retiring President, which I have witnessed at close hand, in achieving a triumph in the diplomatic fringe of our activities. If the solution is not complete, that is certainly not due to any negligence on his part. His patience in this task has been unbelievable and I do not see how any more could have been achieved.

Also I must thank organizers of Symposia and Colloquia for their understanding attitude towards difficult points that have had to be discussed from time to time in presenting their valuable proposals to the Executive Committee.

Et maintenant, j'ai le grand plaisir d'exprimer à ma collègue, Edith Müller, mes remerciements les plus chaleureux pour ces trois dernières années, pendant lesquelles nous avons consacré bien des heures aux affaires de l'Union, et dont nous nous souviendrons avec plaisir. Elle m'a mis au courant des traditions de l'Union Astronomique Internationale, de sa structure, et aussi des espoirs que nous formulons pour notre Union. En tant que Secrétaire Générale, la lourde tâche de l'installation à Paris du Secrétariat, dans ses nouveaux locaux, incombait à Edith Müller - Merci beaucoup, ma chère Edith.

Professor Blaauw, in the Chair, then declared the XVIIth General Assembly of the International Astronomical Union closed. 